\title{
Entrepreneurs' Access to Private Equity in China: The Role of Social Capital
}

\author{
By: Bat Batjargal and Mannie M. Liu
}

William Davidson Working Paper Number 453

April 2002 


\title{
ENTREPRENEURS' ACCESS TO PRIVATE EQUITY IN CHINA: THE ROLE OF SOCIAL CAPITAL
}

\author{
BAT BATJARGAL ${ }^{*}$ \\ Stanford University \\ Main Quad, Building 40 \\ Stanford, CA 94305-2006 \\ Tel: (650) 7233562 \\ Fax: (650) 7256119 \\ Email: batjarga@stanford.edu \\ Batjargal_bat@yahoo.com \\ Guanghua School of Management \\ Peking University \\ Beijing, 100871 \\ China
}

MANNIE M. LIU

School of Finance

Renmin University

Beijing, 100871

China

Email: mannieliu@yahoo.com

\footnotetext{
* We would like to thank Lorna Bian, Jerry Chen and Genfa Chen for their research assistance. We would like express our special thanks to Professor Anne Tsui who guided us on this project from the very beginning. We are grateful to Professor Mark Granovetter, Professor Josh Lerner, Professor Henry Rowen and seminar participants at the Department of Sociology, Asia Pacific Research Center, and the Center for Russian and East European Studies, all at Stanford University, for their useful comments and suggestions.
} 


\title{
ENTREPRENEURS' ACCESS TO PRIVATE EQUITY IN CHINA: THE ROLE OF SOCIAL CAPITAL
}

\begin{abstract}
Drawing on Social network theory, this article argues for enhancing effects of social capital of entrepreneurs on investment selection decisions of venture capitalists (to invest versus not to invest), and main effects of social capital on investment process decisions such as venture valuation, investment delivery speed and contractual warrants/provisions. The core idea of enhancing effects is that the presence of particularistic ties between venture capitalists and entrepreneurs will affect positively investment selection decisions of venture capitalists if only other main factors for investment making such as management team, industry, market attractiveness, proprietary technologies and products are perceived as strong by investors. The context of the study is People's Republic of China. The empirical data is composed of 158 venture capital investment decisions in Beijing and Shanghai. The main finding is that social capital is supplementary and additive to other investment determining factors such as project and team qualities at selection stage, and social capital is a main factor for investment process decisions once a venture has been selected for funding. The main theoretical implication is that social capital may affect outcome variables in interaction with other factors. The main practical implication for entrepreneurs is that social capital is probably necessary but insufficient for raising venture capital successfully.
\end{abstract}

Key words: Social capital, private equity, entrepreneurship, China. 
This article explores the way in which entrepreneurs do access private equity capital and examines the role of personal social capital in obtaining venture finance. Drawing on Social network theory (Bourdieu, 1996, Burt, 1992, Coleman, 1988, Granovetter, 1985, Lin, 2001a) we argue for enhancing effects of social capital of entrepreneurs on access to private equity at venture screening stage. The core idea of enhancing effects of social capital is that the presence of particularistic direct (e.g., prior professional relationship, or interpersonal friendship) and indirect (e.g., third party referral) ties between entrepreneurs and venture capitalists will affect positively investment selection decisions of venture capitalists if only other main factors for investment making such as management team, industry and market attractiveness, anticipated growth rate and proprietary technologies and products (Bygrave \& Timmons, 1992, Timmons, 1994) are perceived as strong by investors. Social capital of entrepreneurs enhances and flavors venture finance decisions in combination with and supplement to main investment determining factors because of the interactive character of investors' rationality and socialized nature of economic exchanges. In addition, we argue for main effects of strong ties between entrepreneurs and venture capitalists on processes of investment decision making such as firm valuation, investment delivery speed and contractual warrants once a venture has been selected for funding. Tie strength is likely to influence investment processes because of information, perceptual, trust and risk reduction benefits inherent in strong relations. Overall, we found significant enhancing effects of social capital on investment selection (to invest versus not to invest) and significant main effects of social capital on investment processes.

We see three contributions of this article to the management research literature. First, this article is first to argue for enhancing or supplementary effects of social capital on outcome variables. The finding that social capital in interactions with other factors 
influences investment selection is a contribution to the social network theory the principal postulate of which is main effects on dependent variables. Second, we demonstrate that social relationships embedded in local cultures and traditions do affect entrepreneurial process and venture investment decisions in unique ways. The way in which entrepreneurs raise capital and investors select ventures to fund is contingent upon local cultural and social contexts (Burt, 1997). Third, to our knowledge, this study is first article that examines impacts of social capital on venture investment decisions in the transition economy context and the Mainland China context. Therefore, we see a contribution to the management research literature on transition economies as well as the Chinese context.

The country context of the study is the largest and fastest growing transition economy - People's Republic of China (PRC). The rationale behind the choice of the research site and context is threefold: First, testing and probing of Social network theory that was initially developed in the Western economic and social environments, in an Asian and transition context provides a unique opportunity to expand, enrich and modify this theory. Second, examining entrepreneurship and decision making in venture capital in the Chinese context sheds lights on how indigenous cultures and institutions shape and influence entrepreneurial processes and investment decisions. This will enable us to understand better contingent features of entrepreneurship and financial decision-making in different contexts. Third, China is a potential economic superpower in $21^{\text {st }}$ century and therefore, it is important practically to study the new entrepreneurial sector that comprises a lion's share of new wealth creation and job generation in the world's most populous country.

Transactions between economic agents are quintessentially social in its core feature. Economic actors, i.e., individuals, groups and organizations, are embedded and nurtured in webs of social relationships (Granovetter, 1985), and as social capitalists, they capitalize on 
resources and assets located in social networks for instrumental actions (Lin, 2001b). The postulate that individual and inter-organizational relationships either facilitate or constrain agents' instrumental actions is widely accepted (Granovetter, 1985). Social capital of actors defined as networks of relationships and resources inherent in these networks (Bourdieu, 1986, Burt, 1997, Coleman, 1988, Lin, 2001a), has positive impacts on firm performance (Baker, 1990) product innovation (Tsai \& Ghoshal, 1998) and industry-wide network formation (Walker, Kogut \& Shan, 1997). Researchers found that social capital of individuals facilitates job and status attainment (Granovetter, 1973, Lin, Vaughn \& Ensel, 1981, Marsden \& Hurlbert, 1988), enhances individuals' power (Krackhardt, 1990) and career mobility (Podolny \& Baron, 1997) and impacts CEO compensation (Belliveau, O’Reilly III \& Wade, 1996).

Research on personal networks of entrepreneurs revealed that entrepreneurs perceive and exploit business opportunities in disconnected networks - "structural holes" (Burt, 1992), obtain information, advice and social support from network alters (Aldrich \& Zimmer, 1986, Birley, 1985, Nohria, 1992), control and manage exchange structures through network dyads (Larson, 1992), access financial capital through contacts (Shane \& Cable, 2001, Uzzi, 1999), and get an endorsement from prestigious players to influence perceptions of the quality of their ventures (Stuart, Hoang \& Hybels, 1999). In the context of transition economies, researchers found that social capital of managers and entrepreneurs affects firm performance indicators such as revenue and profitability (Batjargal, 2000, Peng \& Luo, 2000).

With the exception of Shane \& Cable (2001), there is no empirical research up to date that examines entrepreneurs' access to venture capital through personal social networks. However, there is a large research literature on interactions of entrepreneurs and 
venture capitalists in the post-investment context. Sapienza \& Korsgaard (1996) examined entrepreneur-venture capitalist relationships from the perspective of procedural justice and found that venture capitalists had greater trust in and commitment to entrepreneurs who provided them with more timely. Cable \& Shane (1997) argued that both entrepreneurs and equity capital providers have strong incentives to cooperate in post-investment relationships due to the prisoner's dilemma they face. Researchers also examined staging of venture capital investments (Sahlman, 1990), post-investment monitoring and oversight (Gompers, 1995, Lerner, 1995), contractual terms and negotiations (Hellmann, 1998, Landstrom et al, 1998), interactions between product market and venture capital financing (Hellmann \& Puri, 2000) and geographic and industry localization of venture capital investments (Sorenson \& Stuart, 2001). A descriptive study has found that industry, firm goals and experience of the founder have emerged as differentiating factors in raising successfully private equity among women-entrepreneurs (Brush et al., 2000).

The only research that exclusively focuses on pre-investment relationships of entrepreneurs and venture capitalists is Shane \& Cable (2001). Based on qualitative interviews and survey of seed stage investors, they demonstrate main effects of direct and indirect ties between entrepreneurs and venture capitalists on venture finance decisions. Direct and indirect ties influence the selection of ventures to fund through a process of information transfer.

In contrast to previous research, we would like to argue that social capital has different impacts on investment decisions at varying stages of investment making in the preinvestment context. In venture screening and selection stage, particularistic ties between venture fund seekers and providers are supplementary and additive to universalistic criteria such as quality and experience of entrepreneurial team, technical indicators of products and 
technology, and potential to grow as fast as "gazelles", which venture capitalists consider first as rational investors. If venture capitalist assesses and perceives a new firm as a "potential gazelle" using the universalistic criteria mentioned above, then and only then social capital might be at work: ties are used as information gathering and verification channels as well as control means and devices to mitigate perceived risks and uncertainties on both sides, venture capitalists and entrepreneurs. In interaction with other factors, social capital enhances investment selection likelihood at the stage of screening. Once that decision has been made in favor of the entrepreneur, relational strength of entrepreneurs and venture capitalists is likely to influence the processes of investment negotiations and terms, i.e., valuations, delivery speed and warrants and provisions. Therefore, our overall argument is that social capital is a supplement to universalistic criteria in investment selections but a major factor that affects processes of actual investment making.

\section{THEORY DEVELOPMENT}

The basic principle of investment theory is that investors as rational actors do invest when the present value of the future expected return is greater than the investment because of time-value of money (Brealey \& Myers, 1996). Investors are likely to invest in only those projects, which are expected and perceived to produce an acceptable net present value defined as the present value minus required investment. Investors screen potential projects using industry-wide, universal criteria to identify and discriminate best possible opportunities. In the venture capital context, the quality of management team, industry/market and technology attractiveness, upside potential and downside exposure, stage of development, amount of capital required, founders' goals, control, liquidity and harvest are accepted as the main investment determining factors (Bygrave et al., 1998, Hall \& Hofer, 1993, Macmillan, Siegel, \& Subbanarasimha, 1985, Macmillan, Zeman \& 
Subbanarasimha, 1987). The underpinning logic of investors' rationality suggests that venture capitalists will base their decisions on universalistic criteria rather than particularistic criteria due to the widely-agreed upon, well defined standards for screening and evaluation of funding proposals (Pfeffer et al, 1976). It is assumed therefore that venture capitalists base their decisions on technical merits of each project irrelevant of its social and cultural context.

Investing in new and small firms, however, is regarded as an extremely high risk action because firms have no performance track record and comparable investment to ascertain the expected rates of return (Brealey \& Myers, 1996) and there is a considerable liability of newness and smallness (Stinchcombe, 1965). Also the information asymmetry problem between investors and entrepreneurs exacerbates the risk and uncertainties inherent in new firm creation and development (Shane \& Cable, 2001). Risk and uncertainty are used interchangeably in the present study, and it is defined as "a lack of consensus about purposes and the means of achieving them" (Pfeffer et al., 1976: 230). In the new firm context, venture capitalists and entrepreneurs face varieties of risks: they are uncertain about technological and product outcomes of a project, they lack a consensus on industry and market downside exposure, and they are often unsure about abilities of the management team and the investor (Timmons, 1994). In addition, there is a considerable social risk uncertainties regarding each other's intentions, trustworthiness, personalities and behavioral patterns in the post-investment period (Macmillan, Siegel, \& Subbanarasimha, 1985). A descriptive study by Kaplan \& Stromberg (2000) found that 60 percent of venture capitalists were concerned about social uncertainties such as the founder's motives or personalities. Mitigation of social risk is even more important in this context because both investors and receivers are "locked up" in illiquid investments for at least 5-6 years (Cable \& Shane, 1997, 
Gompers \& Lerner, 1999). Previous research suggests that venture capitalists mitigate different types of risks by employing varieties of strategies, methods and techniques. They focus on certain technology and product areas where they have specialized knowledge and experience, or they co-invest with others who have intimate knowledge about the technology and products (Sorenson \& Stuart, 2001). Venture capitalists do syndicate their investments in certain geographic areas because of information flows and proximity benefits (Sorenson \& Stuart, 2001). Likewise, equity providers prefer to invest in growing industries and promising or overlooked niches of markets where there are less competitions (Timmons, 1994). Venture capitalists assess human capital and abilities of teams by verifying managerial and industry experience, technical skills, reputation, integrity, and marketing skills (Hisrich \& Jancowicz, 1990, Smart, 1998).

The research literature is not concerned with how investors do mitigate social risks, and to what extend investors view social uncertainties as important risks to be dealt with. Despite the underlying assumption of investors' rationality, there is an empirical evidence that investors still try to reduce social risks in venture funding decisions although it is not main criteria for a decision (Macmillan, Siegel, \& Subbanarasimha, 1985, Kaplan \& Stromberg, 2000).

Decision making theory in high uncertainty situations postulates that the greater the uncertainty the more likely that economic agents will choose particular exchange partners with whom they have had prior transactions (Podolny, 1994). This happens because actors tend to search exchange partners among those about whom they have better knowledge and be satisfied by the results (March, 1988), and actors tend to compare themselves with socially similar others and employ particularistic criteria such as social relationships to make the decision and resolve the uncertainty (Pfeffer, et al., 1976). Actors are assumed to have 
better knowledge about those players with whom they have enduring relationships (Granovetter, 1973) and therefore, decision makers are likely to favor those actors with whom they have particularistic ties given other decision criteria are satisfied. In socially uncertain situations, actors are likely to enter in exchange relations with those of similar positional status (Podolny \& Castellucci, 1999) and those who possess similar demographic characteristics (Tsui, Egan, \& O'Reilly, 1992) because relational trust in and history with contacts makes actors to feel that they reduce uncertainties surrounding their purposes and outcomes (Molm, Takahashi, \& Peterson, 2000). Uncertainty will generally be higher in newer markets, e.g., venture capital, than in more established ones, since there will typically be less knowledge of quality distinctions and overall supply and demand in the former (Podolny, 1994). Considering the multiplicity of risks, venture capitalists are likely to base their decisions on interactive trade-offs of technology, products, market potential and social familiarity (Muzyka, Birley \& Leleux, 1996). It is therefore assumed that venture capitalists are likely to invest in ventures of those entrepreneurs with whom they have had prior direct and indirect relationships given the main investment criteria are met. A social certainty will play a complementary role in selection decisions due to social comparison processes that are used to neutralize risks inherent. Thus, social capital of entrepreneurs enhances and facilitates likelihood of raising private equity.

\section{THE VENTURE CAPITAL INDUSTRY IN CHINA}

Ever since economic reforms were launched in late 1970s the entrepreneurial spirit is in the rise in China despite occasional setbacks due to macro-economic and policy uncertainties. There were about 6 million state and collective enterprises (28 percent - state owned enterprises, and 72 percent - township and collective companies/corporations), 1.5 million private companies and 31.6 million private partnerships at the end of 1999. The 
number of private companies had increased 15 folds from 1991 to 1999 (State Industrial and Commercial Registration Bureau, 2000). The venture capital industry in China has experienced the same development patterns. Although first domestic venture capital firm was set up back in 1986, VC industry has intensively developed only after March 1998 when the Chinese government adopted a number of policy schemes to promote private equity investments. According to a recent research, there were 180 venture capital firms functioning in China in July 2001 (Table 1). Total funds under management reached \$US 1.87 billion. There were 120 dedicated domestic VC firms owned by the central government, provincial and municipal governments, and private companies, and there were 60 foreign VC firms (Liu \& Wang, 2001).

Despite its "infant" age and the global economic turmoil, the Chinese VC industry is still relatively active. There are certain features that characterize the VC industry in China. Government investments in VC funds are declining dramatically: in 1986 all the funds were government-backed whereas by July 2001 only 50 percent of money in funds were originated from government sources (Liu et al., 2002). This indicates that more and more private sector firms are setting up VC funds. Especially, publicly listed firms are expected to play a major role in $\mathrm{VC}$ investments. While foreign owned $\mathrm{VC}$ firms are affected by stock market fluctuations in the West, domestic firms are more constrained by the delayed opening of secondary board market. The dominance of the China's financial system by a few state-owned, inefficient and unreliable banks seems to facilitate resource flows into VC funds. Although the Chinese VC industry has taken off the ground rather well, there are some serious institutional, regulatory and human capital issues to be dealt with. Limited exit routes for VC backed firms, deficient legal and regulatory framework, lack of trained fund managers, and closed clique-type networks seem to hinder development of VC industry 
(Cheng, 2000, Zhang, 2000). For example, about 40 percent of fund managers in domestic VC firms were government officials and only 4 percent had prior fund management experience (Liu and Wang, 2001). Most VC firms in China prefer to invest in later stages of venture development (Cheng 2000, Zhang 2000, Zhang 2001). Due to the vague legal definition of partnerships in the Chinese law, domestic VC firms are registered as companies and corporations. This puts restrictions on how much capital can be invested in new entrepreneurial firms. Also many VC firms are active investors in stock markets.

\section{SOCIAL CAPITAL IN THE CHINESE CONTEXT: GUANXI}

The idea of social capital in the Chinese context is captured by the indigenous social phenomenon called guanxi. Although there is a mild debate about exact definitions of guanxi (Bian, 2001, Lin, 2001c, Tsui, Farh \& Xin, 2000, Walder, 1986, Yang, 1994, Yeung, $\&$ Tung, 1996), there is an agreement among researchers on it's core meaning: guanxi is interpersonal relationships that facilitate social exchanges. The research literature on guanxi suggests four overlapping yet slightly different interpretations of the phenomenon.

An ethnographic research defines guanxi as the web of extended family relationships (Bian, 2001, King, 1985). The family serves as the core base for guanxi, and relationships are strongly sentimental and expressive. There is a strong hierarchy within the family pyramid where the oldest male is the head of the clique. The way guanxi functions is one of a closed clique: there is a cohesive set of actors (family members) whose roles, obligations and expectations are clearly defined and re-enforced. There are also established rules, sanctions, traditions and symbolic rituals that sustain relationships.

Another popular interpretation of guanxi is the perspective of utilitarian ties: guanxi is a cluster of exchange relationships for instrumental purposes (Bian, 2001, Walder, 1986, Yang, 1994). The core feature of guanxi, in this sense, is the instrumental value of getting 
things done through relationships. Walder (1986) examined personal relationships of state officials versus enterprise directors, party officials versus party activists, and shop-floor supervisors versus ordinary workers through this prism. Although major characteristics of guanxi such as relational strength or content remain valid in this definition, the emphasis is on material reciprocity as the dominant rule of the game. Instrumental gift giving and receiving, or social eating (Bian, 2001, Yang, 1994) are examples of utilitarian reciprocity in guanxi relationships.

Lin (2001c) suggested a "sentimental" interpretation of guanxi the underlying idea of which is that in contrast to economic exchanges, social exchanges are always asymmetric because actors focus on long-term commitment to maintaining relationships rather than short-term utility maximization. Actors go into relationships for the sake of the relationship. "It is, Lin (2001c: 22) writes, the relationship that is valued and must be maintained, not the value of the favor transacted per se." The sentimental-emotional aspect or renqing of guanxi is emphasized here.

Referring to the Confucian cultural legacy of China, Tsui, Farh, \& Xin (2000: 226) defined guanxi as a special relationship due to the existence of particularistic ties. Yeung \& Tung (1996) proposed a similar interpretation of guanxi as a cultural subsystem embedded in Confucian values as opposed to social relationships based on Western values. Guanxi as a complex and multifaceted phenomenon is interpreted through bases for guanxi (e.g., family ties versus acquaintances), modes of relationships (e.g., identification versus friendships), and proximal and distant outcomes (e.g., trust, loyalty, or career and business success). There should be a base for establishing a guanxi. It is given in the case of family. Other factors such as common background may serve as a base for guanxi. Relational strength, content and modes differ contingent upon guanxi base. The model of guanxi as a system 
proposed by Tsui \& Farh (1997), and Tsui et al (2000) suggests complex interactions of bases for guanxi, relational and psychological features of guanxi and its social and instrumental outcomes. This conceptualization of guanxi has been linked to the theory of relational demography: demographic characteristics of network ties, e.g., age or gender, will have influences on network structures and relational aspects of ties such as tie strength, content and activation mode (Tsui \& Farh, 1997, Farh, Tsui, Xin \& Cheng, 1998). The notion that demographic characteristics of ties influence structural and relational dynamics of networks in important ways has been an aspect that is largely overlooked in social network theory. Incorporation of demographic, cultural, social, human capital and occupational (Lin, Fu, \& Hsung, 2001) characteristics of network alters in guanxi analysis will enable us to identify and explain the way guanxi influences outcomes of purposeful actions such as venture investment.

Empirical research on guanxi has produced largely confirmatory results of positive effects of social relations in the Chinese context on outcome variables. Guanxi capital (Bian, 2001) promotes interpersonal trust at supervisor-subordinate relationship level (Farh, Tsui, Xin \& Cheng, 1998), facilitates job mobility (Bian \& Ang, 1997) and serves as hedging substitutes for institutional and legal deficiencies (Xin \& Pearce, 1996). In the entrepreneurial context, embedded in Confucian values guanxi relationships indirectly decrease transaction costs of firms (Cheung \& King, 2001), link overseas Chinese entrepreneurial clusters (Butler, Brown \& Chamornmarn, 2000), enhance firm-level performance (Yeung \& Tung, 1996), and contribute to wealth creation (Peng, 2001). There might be however possible negative effects of guanxi on outcome variables because of a strong sense of group and favoritism in guanxi relations (Tsui \& Farh, 1997). 
Qualitative research evidence suggests that guanxi does play a role in entrepreneurial and venture capital decision making in China (Liu, 1999). The hybrid institutional structures of Confucianism, Communism and Local capitalism emergent in China (Child \& Boisot, 1996, Nee, 1992, Oi, 1992) influences the way in which venture capitalists raise money for new funds and make investment decisions. A substantial portion of cash that goes into VC funds originates from government sources in China. Therefore, guanxi relationships of VC fund managers with government officials are often regarded as a defining factor for securing of government investments in VC funds. Given the increasing marketization of the Chinese economy however guanxi relationships will serve more and more as a risk mitigating device in $\mathrm{VC}$ investments rather than practices of nepotism and favoritism in decision making.

\section{HYPOTHESIS}

\section{Prior Relationship and Referral}

Given the technical aspects of a venture project (technology, team and potential) have been assessed as strong, we predict that those entrepreneurs who have had prior social relationships with venture capitalists will be able to raise successfully private equity capital for their firms. Particularistic ties make a difference because investors possess tacit knowledge about behavioral history of entrepreneurs and engaging experience with them. This will enable them to make judgmental projections about entrepreneurs' behavioral patterns such as predictability, honesty and trustworthiness. Empirical evidence suggest that investors scrutinize such personality qualities of entrepreneurs very carefully (Macmillan et al, 1985). Prior professional relationships verify networking skills and contact resources of entrepreneurs, which is a core advantage in the economy of guanxi wuan - webs of relationships (Lin, 2001c), in addition to routine due diligence check-ups on human capital. On the entrepreneur side, relationships will serve as filters to approach those investors who 
are known for being patient and able to add value (Sapienza, 1992). Informal socializations such as social eating, an extremely important part of the Chinese culture (Bian, 2001, Yang, 1994), will enable both investors and fund seekers to know values and beliefs of each other better, and facilitate interpersonal and cognitive trust in each other's abilities and intentions. Cultural features of the Chinese such as a strong sense of social obligation, favoritism and inclinations to categorize people into "inner" and "outer" circles (Farh, et al., 1998) may also facilitate better communications of investors and entrepreneurs who know each other. Thus, dyadic ties defined as unordered pairs of actors and the arcs that exist between the two actors in the pair (Wasserman \& Faust, 1994: 510) will enhance entrepreneurs' access to venture capital. A previous research has found consistent evidence with this theorizing. Yeung \& Tung (1996) found that Chinese entrepreneurs regard guanxi as one of many important factors, e.g., products or capability, for entrepreneurial success, and concluded that having guanxi is necessary but insufficient for long-term growth. Our own interviews with Chinese venture capitalists do confirm this logic and finding.

A Shenzhen based venture capital firm - Guocheng Ventures invested in a high tech firm called Haidewei Biotechs in 1998. The lead general partner of Guocheng Ventures - Ma, knew Zhang, one of the founders of Haidewei Biotech before. They were friends for many years. Zhang told about his new venture to Ma in late 1997. Knowing that Zhang is a trustworthy, hardworking and able person, Ma introduced Zhang to his own VC partners with delight. After careful assessment of the technical indicators of the venture, Guocheng invested $\$ 535,000$ in Haidewei. Two and a half years later, Guocheng exited successfully turning the original sum into $\$ 2.5$ million - more than 4.5 times.

In high uncertainty situations such as new venture investment, prior relationships

serve as a social risk reducing device, and therefore, it is likely to facilitate investment inflows given the universal criteria are met. We propose:

Hypothesis 1: The entrepreneur is more likely to obtain an investment if the entrepreneur has a prior positive relationship with the venture capitalist given the technology/product, entrepreneurial team, growth potential of the venture and business plan are perceived as strong by the venture capitalist. 
As a type of triadic ties, which are defined as unordered triples of actors and the arcs that exist between the three actors in the triad (Wasserman \& Faust, 1994), third party referrals are expected to influence investment decisions of venture capitalists assuming the technical merits of a venture are perceived as strong by investors. A previous research found that network size of individual entrepreneurs is constrained by ceiling effects - the actual number of ties that could be managed by a person limits the absolute number of contacts in any personal networks (Batjargal, 2002). Therefore, direct ties have limited ranges of opportunities or "structural holes" (Burt, 1992). Consequently, entrepreneurs and venture capitalists deliberately search out more and better opportunities through the practice of third party referral. Referrals lead to greater pools of actors (Fernandez, Castilla \& Moore, 2000), which may be conducive to better venture projects and ideas. Trusted sources - referees serve as information filters about opportunities and trends, and this filtering may reduce search and identification costs at the screening stage (Burt, 1992). Finding a venture team or venture capitalist through third party referrals may facilitate matching between investors' and entrepreneurs' preferences and policies because sides do know each other's preferences better. Also members of triads are likely to cooperate and comply with exchange rules in triads because of a strong normative power of triad members (Granovetter, 1985, Krackhardt, 1998). The Chinese context adds culture-specific variables that also affect investment selections through referrals. In the culture of shame, favor giver (the one who recommends someone to a third party) is regarded as a face giver, and favor receiver (the one who gets access to third party through the recommendation) is regarded as a face receiver (Lin, 2001c). Successful transactions between face giver (referee), face receiver (fund seeker), and investor will enhance face - mianzi (social standing, symbolic resources and reputation) of all parties (Lin, 2001c). Also face giver - referee would hesitate to 
recommend someone to a third person if he or she is not confident about successful outcomes because of fear of loosing face (shi mianzi) of all parties involved (Lin, 2001c). Although brokerage or bridging is wide-spread in China, it is important to note that the Chinese seem to have mixed feelings about this role: on the one hand, they admire or approve those who have powerful guanxi, and on the other hand, they are cautious of guanxi masters - neng ren who may take advantage of them.

A qualitative evidence is consistent with the proposition that referrals affect venture finance decisions.

A Tianjin based VC firm - New Era Ventures - invested in a company called Gwcom.com in 1999. Lan, the CEO of New Era Ventures, admitted that the investors would have been much more cautious if he and $\mathrm{Li}$, the referee for the founder of the firm (Wang) did not enjoy a long history of friendship. Lan, a successful venture capitalist in China, led the New Era Ventures from \$US2.5 million fund to \$US12.5 million fund in less than two years. Lan met Wang at a conference through a mutual friend - Li. Lan and Li had worked together before and have enduring friendship for more than a decade. Lan became interested in Wang's project, a Chinese wireless palm computer, the main technological attraction of which was capability to read and write Chinese characters. It was an important innovation in China at that time. Because of the recommendation of Li, Lan did invest in Wang's venture.

Clearly, without the third party referral, outcomes of negotiations could have been different. Thus, third party referrals may improve chances of obtaining of venture capital because of opportunity filtering, information and trust benefits that mitigate social risks in decisions.

Hypothesis 2: The entrepreneur is more likely to obtain an investment if the entrepreneur has been recommended to the venture capitalist by third parties whose judgment the venture capitalist trusts given the technology/product, entrepreneurial team, growth potential of the venture and business plan are perceived as strong by the venture capitalist.

\section{Strong Ties}

Once a venture was selected for investment, negotiations about components of the deal begin. This context is substantially different from the selection stage because all the venture projects have passed successfully the threshold of a promising venture. We predict 
therefore that strong ties between entrepreneurs and venture capitalists do influence investment processes such as valuation, delivery and warrants due to the tangible and intangible benefits of relational strength.

We propose that tie strength will be associated with better valuations of the new venture. Friendly relations of investors and venture capitalists are likely to lead to finetuned, honest and precise information exchanges between the venture team and VC firm. This may enable investors to do in-depth due diligence, and may increase confidence in the venture's success. This projected success of the venture may incline investors towards better valuations of tangible and intangible assets of the firm. High-trust relationships may bias exchange partners in each other's capabilities and resources, and these biases may influence positively valuation negotiations. Friendships may also reduce perceived risks of opportunistic behaviors such as machinations in investment flows, revenues and cash-flows on both sides. This lowered perception of opportunism may reflect positively on venture's worthiness. Interpersonal liking and emotional idiosyncrasies between friends may also provide a broader room for value negotiations, which may be conducive to better valuations. Peculiarities of the Chinese negotiation behavior are likely to lead to increases in venture values. A sense of balance, modesty and mutuality is likely to smooth out negotiation processes where acceptable compromises are crafted out. For example, a Chinese entrepreneur said:

When the Chinese people said it is a blessing to take less than you actually deserve, they did not say that you should always do so. The point is that you endeavor to take less, so that the other party will not let you to take less, then the whole enterprise will become prosperous. On the other hand, if you do not want to take less, the result will just be the opposite, because the other will try his best to make you take less (Cheung \& King, 2001: 52).

This mind-set of "give more and you will get more" may also result in higher values of ventures. Because guanxi is a public good where information diffusion is efficient and 
credible (Lin, 2001c) both investors and entrepreneurs may be pressurized not to be too persistent and aggressive, and this may influence negotiation postures of investors and managers. In this way, those entrepreneurs who have friendship ties with general partners of VC firms are assumed to get better values for their firms. The next proposition is:

Hypothesis 3: The stronger the tie between the entrepreneur and venture capitalist, the higher the valuation of entrepreneurs' firms.

A conventional logic suggests that friendly ties between fund providers and seekers will facilitate speedy negotiations and faster investment deliveries due to the perceived certainties in strong ties. In this sense, the stronger the tie the faster the investment delivery. Our prediction however is the opposite of this intuition. It is assumed that relational strength will be associated negatively with investment speed. In friend versus friend circumstances, there will be a plenty of information to digest on both sides, and it will slow down the decision making process. Because general partners and entrepreneurs are friends, there is a less probability on both sides to pool out of negotiations unpredictably and this will lighten up the time pressure on negotiators. An essential characteristic of guanxi is its long-term and sustainability orientation (Lin, 2001c). Strong ties are likely to be perceived as accessible and proximate by the Chinese. A sense of accessibility and proximity is likely to re-direct attention, time and resources of investors and managers to other competing activities. An empirical research on decision making processes in China found that the more the Chinese know about the opposite side the more likely to play a gentle game of forward and backward moves (Quanyu, Leonard \& Tong, 1997). Field interviews support this statement. The lead general partner of the VC firm set up by the China Aerospace Science and Technology Corporation said in an interview:

Well, to do business with your friends is more complicated than with strangers. You have to be very careful not to offend your pal. But you also have to think about business too. When you assess possibilities to invest in your friends' venture there seems to be almost a sense of 
relief or relaxation. You do not feel a competitive pressure. You feel you know everything about him and his business. There is no a sense of urgency on both sides. And plus you have to follow all these Chinese rituals and routines with your friend. All these slow down the whole thing. I am in talks with my childhood friend. It is going on and on. But we will get there one day (Author's interview, Beijing, July 2001).

The underlying logic and findings let us to formulate the next proposal:

Hypothesis 4: The stronger the tie between the entrepreneur and venture capitalist the longer the investment delivery period.

Our last hypothesis is on contractual provisions and warrants, which protect investors' interests. It is proposed that those general partners who have strong guanxi ties with the entrepreneurs are less likely to legalize all the terms and conditions of investments in formal contracts. In the Chinese context, venture capitalists are likely to invest more in common stock rather than other senior securities such as convertible preferred stock, nonconvertible preferred stock, debt coupled with common stock, or common stock purchase warrants. Insisting on complicated securities that directly protect VC interests may send a signal of distrust and reduced commitment to the entrepreneurial team who have friendly relations with VC fund managers. Therefore, investors are likely to scale down attached terms and conditions, which in its turn cut down the number of formal provisions in contracts. The Chinese are said to be more situational. They would prefer to keep details of guanxi deals confidential (Lin, 2001c) and resolve potential issues and problems through tacit understandings and actions. Precise calculations of dividends, conversion, liquidation, and anti-dilution terms may reduce commitments of the entrepreneurial team and are likely to be perceived as unenforceable by investors and entrepreneurs. Investors also may view fewer warrants as another device to cultivate even deeper trust with their friends. This line of thought is supported by qualitative evidence. The lead fund manager of China Equity Investment said in an interview: 
First, in China we do not know these warrants and financial devices you are talking about. Even if we know them they will be useless because our legal framework and financial system is insufficient to re-enforce them. The Chinese therefore will not believe in them. Second, if you keep saying I want this and I want that in negotiations with your friends, it will be perceived as though you are planting seeds of future conflicts, and people will regard you as selfish. If that is the case, a very few will be willing to do business with you. I think you will not find long lists of provisions in Chinese VC contracts" (Author's interview, Beijing, June 2001).

Therefore, we state:

Hypothesis 5: The stronger the tie between the entrepreneur and venture capitalist the fewer the number of provisions and warrants, which protect venture capitalists' interests.

\section{METHODOLOGY}

\section{Sample and Data Collection}

We created a list of 160 domestic venture capital firms in China using several data sources: the data-base of VCChina, the only consulting firm specialized in venture capital investments in China, internet sources (skyventure.com, chinatec.net, c-vcc.com), and interviews with academics and practitioners in VC industry in Beijing and Shanghai. We identified 43 VC firms in Beijing and 19 firms in Shanghai. This comprises 38 percent of all domestic VC firms in China. The only other city that has numerous VC firms is Shenzhen (24). In Beijing, we approached 30 firms selecting every second and third in the list and 22 agreed to participate in the study (the response rate is 73 percent). In Shanghai, we contacted 19 firms and 18 firms accepted our request to give interviews (the response rate is 94 percent). In all, 23 CEOs and general partners were interviewed in Beijing and 19 CEOs and general partners were interviewed in Shanghai.

Prior systematic interviews, we conducted 7 semi-structured pilot interviews with CEOs and lead fund managers of VC firms in Beijing from November 2000 to April 2001. Interviews were conducted in English and Mandarin Chinese. Each interview lasted about 
two hours and all the information were recorded, and used for design of the survey instrument.

The questionnaire was designed in English. The English version was translated into Chinese by a team of three scholars based at Renmin University's School of Finance in Beijing. Two scholars of management at Peking University back translated the Chinese version into English. We compared two versions and eliminated any inconsistencies in wording and translations. In addition, we pre-tested our questionnaire with three fund managers and two entrepreneurs in Beijing in June 2001. Appropriate changes in question formulations and wording were made upon the completion of pre-testing.

The method of data collection was face-to-face interviews with CEOs and general partners. Two research officers at Peking University and a consultant at VCChina office in Shanghai conducted interviews in Mandarin Chinese under the close supervision of the authors. Each interview lasted about an hour. The questionnaire contained 8 questions on venture capitalist and 24 questions on venture investment decisions. We asked each general partner to select the last two positive investment decisions (VC firm decided to invest) in 2000, and the last two negative investment decisions (VC firm decided not to invest) in 2000. Thus we collected information on four investment decisions maximum from each respondent. In this way, investments were selected randomly within two groups. In total, we collected information on 76 positive investment decisions and 82 negative decisions.

\section{Variables and Measurements}

Focal Independent Variables and Measurements

Independent variable is social capital of the entrepreneur. Social capital is measured by prior relationship scale, third party-referral scale and strong ties (Shane \& Cable, 2001). The social capital measurements were multi-item, evenly weighted scales. Distribution 
values of each question were five-point Likert scale items ranging from strongly agree (5) to strongly disagree (1). We computed each scale by adding up the values in each item and dividing them by the number of items. We adapted the items from Shane and Cable (2001) although we had to re-formulate them for investors rather than entrepreneurs themselves.

The prior relationship scale between the entrepreneur and venture capitalist was comprised of three questions (Cronbach alpha is 0.78 ). These questions were: “As a venture capitalist, I had a professional relationship with the entrepreneur prior seeing the business plan"; "As a venture capitalist, I had engaged in informal social activities, e.g., dinners and other social activities, with the entrepreneur prior seeing the business plan"; "The entrepreneur was a personal friend prior seeing the business plan".

The referral scale was measured by four items (Cronbach alpha is 0.72): "Someone whom I trust to discuss important confidential matters knew the entrepreneur"; “A third party whose judgement I trust provided me with non-public information about the entrepreneur"; "I could obtain information about the entrepreneur from my network of contacts faster than other investors could obtain the same information"; "By calling people I know, I could obtain information about the entrepreneur in a relatively inexpensive manner".

Strong ties was measured by a friendship item: "The entrepreneur was a personal friend prior seeing the business plan".

Dependent Variables and Measurements

Dependent variables were investment selection decision, venture valuation, speed of investment delivery, and contractual warrants and provisions.

Investment selection is a binary variable of one if the venture received the investment and zero if the venture did not receive the investment. 
Venture valuation was measured by the difference in percentages of the initial valuation of the firm by the investor and the final valuation of the firm by the investor. We asked two questions about the initial valuation: "What was the initial size of investment (RMB - the Chinese currency) you offered to the venture team"; "What was the initial equity you sought in the venture (in percentage)". All data in RMB were deflated by the 2000 year's average of exchange rate of RMB and \$US published in The Economist. From this data we calculated the value of the venture initially put forward by the venture capitalist (London Business School, 1997). We asked two questions about the final valuation: "What was the final investment amount (in RMB) you decided to invest in the venture": "What was the percentage of equity your VC firm has received for the investment". From this information we calculated the final value of the venture accepted by the venture capitalist and the entrepreneurial team. The difference between the initial value and the final value was calculated, and it was expressed in percentage in relation to the initial value. This number is venture valuation measurement.

Speed of investment delivery was measured by the number of months from the date of positive investment selection decision to the date of first injection of the investment into the venture. We asked the date of investment selection decision and the date of first installment, and from these we calculated number of months.

Contractual provisions/warrants was measured by the number of provisions/warrants in contracts, which protect the $\mathrm{VC}$ interests. We asked a question: "How many provisions and warrants, which protect your firm's interests, were formalized in the final contract". Control Variables and Measurements

Control variables were region, industry, initial investment sought by the entrepreneur, investment stage, experience of general partners in $\mathrm{VC}$ fund management, 
number of investments under management, number of business plans received in 2000, age of VC firm, size of VC firm. We control for these factors because researchers found that these variables do influence access of entrepreneurs to private equity (Bygrave et al., 1998, Hall \& Hofer, 1993, Macmillan, Siegel, \& Subba Narasimha, 1985, Macmillan, Zeman \& Subba Narasimha, 1987, Timmons, 1994). Some of the controls were included because our field interviews indicated that these variables affect venture finance decisions of investors.

The regions are Beijing, the China's capital city, and Shanghai, the business center of China. Industries include Internet/IT, biotechnology, service, manufacturing, telecom, and engineering/new materials. The initial investment amount sought by the entrepreneur is expressed in \$US. Investment stage was measured by pre-revenue stage and pre-profit stage. Pre-revenue is a binary variable of one if the new venture has had no revenues by the time they approached the VC firm and zero if the venture has had revenues by the time they approached the VC firm. Pre-profit is a binary variable of one if the venture has made no profit prior venture investment, and zero if the venture has made profit prior investment. Experience of general partners in VC fund management was measured in years of working as a venture capital partner. Investment under management was measured by the number of venture deals under the direct management of the venture capitalist. The number of business plans received in 2000 was captured by the question "Approximately, how many business plans have you received from entrepreneurs in 2000?'. Age of VC firms was measured in years of operation as a VC firm. The number of full time employees captured size of VC firm.

Moderator Variables and Measurements

Technology/products, quality of the entrepreneurial team, growth potential of the venture, and perceived quality of the business plan are moderator variables. The 
measurements for technology/products, entrepreneurial team, growth potential of the venture, and quality of business plan were multi-item, evenly weighted scales. Technology/product scale and business plan scale items were adapted from Shane \& Cable (2001). Technology/products scale is composed of two items (Cronbach alpha is 0.72): "The technology employed or products offered by the venture would provide a significant competitive advantage"; "The venture's technology had a strong proprietary position". Business plan scale is comprised of two items (Cronbach alpha is 0.76 ): "The business plan was thorough in its coverage of key issues"; "The business plan did an excellent job of articulating the opportunity". Growth potential scale is measured by two items (Cronbach alpha is 0.71 ): "The venture is a potentially high growth firm"; "The venture's competitive strategy is superior than its competitors". Team scale is composed of two items (Cronbach alpha is 0.76 ): "At least one member of the venture team had previous startup experience"; "At least one member of the venture team had experience in the relevant industry". Construct Validity

In addition to Cronbach's alpha, we conducted a confirmatory factor analysis of the measurement model associated with Likert scale items to assess how well our interview questions load onto the constructs. Results indicate that fit of our model and the data is reasonable. We found that the comparative fit index is 0.89 , the incremental fit index is 0.91 , and the root mean squared error of approximation is 0.078 . These indicators are regarded as acceptable by researchers. In addition, we carried out a factor analysis that focused only on independent variables: fit indexes were above 0.85 and the factor loading was acceptable (the average on-factor loading was 0.63 ). The findings suggest that our data are valid internally. Shane \& Cable (2001) did the same analysis for the same question items and found even better results. Their findings re-enforce the external validity of our constructs. 
Since our questions on prior relationships are perceptual items, we did validate these data by calling up 12 randomly chosen entrepreneurs in Beijing. We asked 3 questions on prior relationships and compared the answers with the venture capitalists' perceptions of their relationships. They were fully consistent with the information we collected from the general partners. This also strengthens the external validity of our measurements.

\section{RESULTS}

\section{Descriptive statistics}

Table 3 presents descriptive statistics and Pearson's correlations between variables. Means for prior relationships and referrals are consistent with the logic that most people will have more indirect ties (referrals) than direct relationships. Four moderator scales (technology, growth potential, team and business plan) are above three, and this may indicate that self-selection process is at work. Only those entrepreneurs who think their products and plans have chances to be funded do approach VC firms. Team scale is the highest, and this is consistent with findings in the West that people who have industry knowledge and experience tend to start businesses in relevant industries. A surprising finding was that firms in Internet/IT business comprise more than 50 percent of the sample given the recent defaults of many Internet firms in the West. This may indicate a different cycle of the Chinese economy as well as the adolescent nature of Internet industry in China. An expected result was that two-thirds of firms that seek venture capital were in the growth stage. Also the mean for initial amount sought is high ( $\$ 1.7$ million) by developing country standards. The other findings are more or less consistent with our expectations.

\section{Investment Selection}

Table 4 demonstrates the results of logistic regression analysis predicting the investment selection as a function of interactions of social capital with other investment 
determining factors. We are aware that our sampling method of venture decisions is retrospective. This retrospective feature does not influence differences on the logistic scale although it affects intercepts (McCullagh \& Nelder, 1999). The model 1 is the base model, which includes all control and moderator variables. Shanghai and other high tech dummies are the reference groups. The model shows that technology/products, entrepreneurial team, and growth potential of venture are associated positively and significantly with investment selection. The model is significant (chi-square is $148.29, \mathrm{p}<0.001$ ). The model 2 demonstrates impacts of focal independent variables (prior relations and referrals) on investment selection decisions. It illustrates that none of two social capital variables have main effects on the probability of venture investment selections. The model is significant (chi-square is $150.92, \mathrm{p}<0.001$ ).

Models 3-6 present effects of prior relationship and its interactions with four moderator variables (technology, team, growth potential and business plan quality) on investment selection (Jaccard, 2001). These models demonstrate findings on hypothesis 1. Model 3 indicates that interaction effects of prior relations and technology are not significant although causal direction is positive. The model is significant (chi-square is 150.95, $\mathrm{p}<0.001)$. Model 4 shows that interactions of prior relations and team are not significant although the causal direction is positive. The model is significant (chi-square is 151.06, $\mathrm{p}<0.001)$. Models 5 and 6 demonstrate that interaction effects of prior relations and growth potential, and interactions of prior relations and quality of business plan are positive and significant. Both models are significant (chi-square is $157.71, \mathrm{p}<0.001$, chi-square is 155.26 , $\mathrm{p}<0.001$ accordingly). In models 5-6, we find a partial support for hypothesis 1 .

Models 7-10 present results on how interactions of third party referral with moderators are related to investment selection. In Model 7, we see that interactions of 
referral and technology have positive and significant impacts on likelihood of investment selection. The model is significant (chi-square is $150.98, \mathrm{p}<0.001$ ). Model 8 reveals that interactions of referral and entrepreneurial team are positively and significantly associated with probability of being selected for investment. The model is significant (chi-square is $151.16, \mathrm{p}<0.001)$. Model 9 indicates that interactions of referral and growth potential influence positively chances of obtaining private equity. The model is also significant (chisquare is $156.59, \mathrm{p}<0.001)$. Model 10 indicates that interactions of referral and business plan quality are not correlated with investment likelihood. Moreover, the causal direction is negative. The model is significant (chi-square is $155.68, \mathrm{p}<0.001$ ).

Thus, findings in models 7-9 do support hypothesis 2 that those entrepreneurs who have been recommended to the investor by a trusted source are likely to secure venture finance.

\section{Valuation, Investment Speed and Warrants}

We present our findings on how strong ties impact investment processes such as valuation, delivery speed and warrants in Table 5. Regression analysis illustrates that strong ties predict venture valuation, investment delivery speed and warrants. In addition, findings suggest significant effects of region (Beijing dummy) and experience on outcome variables.

Model 1 is the base model for venture valuation. Although the model is not significant $(\mathrm{F}=1.26)$, Beijing dummy is associated positively with better venture valuation. Model 2 reveals positive effects of strong ties on venture valuation changes. Experience of venture capitalist also predicts better valuations. The overall model is significant $(\mathrm{F}=5.78$, $\mathrm{p}<0.001)$. Model 3 is the base model for investment delivery speed and it is not significant $(\mathrm{F}=1.43)$. In model 4 , we see positive and significant effects of strong ties on investment 
delivery speed although the overall model is not significant. The stronger the tie the slower the investment installment. Model 5 is the base model for warrants and it reveals that region - Beijing dummy has positive effects on contractual provisions and warrants although the overall model $(\mathrm{F}=1.71)$ is not significant. In model 6 , we found significant negative effects of tie strength on contractual warrants. The stronger the relationship the fewer the provisions, which protect investors' interests, in written contracts. The model is significant $(\mathrm{F}=1.78, \mathrm{p}<0.05)$. Thus, hypotheses 3 on venture valuation, hypothesis 4 on investment delivery speed, and hypothesis 5 on warrants/provisions have been confirmed by the findings. Tie strength influences significantly processes of investment decisions.

\section{DISCUSSION}

Hypothesis One that direct ties of entrepreneurs and venture capitalists are likely to enhance entrepreneurs' access to venture capital in interaction with universal decision criteria such as technology, team, growth potential and quality of business plan has been confirmed partially. Consequently, we state that particularistic ties of VCs and entrepreneurs are supplementary to primary investment decision factors due to the risk mitigating role of direct contacts in high uncertainty situations. Direct ties do mitigate risks through judgmental projections about venture's success and behavioral patterns of entrepreneurs based on relational history, ascertaining network and positional resources of entrepreneurs, and identifying accurately personal qualities of entrepreneurs such as attitudes, values, mental stamina and drive to succeed. A cultural inclination of the Chinese to favor those whom know also contributes to risk mitigating role of prior professional and personal relationships in venture financing in the Chinese context.

Hypothesis Two that indirect ties (third party referrals) are likely to influence investment selection decisions of venture capitalists in interaction with universal decision 
making criteria of technology, management team, growth perspective and perceived quality of business plan is affirmative. Social referral reduces uncertainties surrounding new venture finance in a number of ways. The venture capitalist "disperses" some of the risks to the referee (the one who recommends) so that in case future transactions and relationships are unsuccessful he can protect his own reputation and social standing among the entrepreneurial and the venture capital community by blaming the referee. Through third parties, investors filter and screen projects and teams from larger pools. It increases chances to find better projects in technical terms, and able and less opportunistic management teams. On the referee side, he/she is likely to recommend only those who have promising projects and those who proved themselves as reliable and trustworthy exchange partners. This selection will have two opposite implications contingent upon the outcome: if the transaction is successful it will enhance the referee's own social standing and influence, and if it is not successful it will harm his reputation and standing within the entrepreneurial and VC community. Therefore, the referee will be selective, and this directly mitigates the venture capitalist's social risk. Such social calculations are especially widespread in the culture of guanxi where results of transactions become immediately public through efficient information diffusion channels among members of particular guanxi clusters (Lin, 2001c). Third party referrals may lead to better matching not only in terms of investment preferences such as industry or market niche, but also in terms of social matching: the right personal chemistry between the investor and the entrepreneurial team is likely to mitigate risks of future conflicts and reduce costs. There will be strong mutual pressures and expectations among the triad members in this context (Krackhardt, 1998). This influences indirectly investment selections. 
Hypothesis Three anticipated that those entrepreneurs who have friendly relationships with equity investors are more likely to get better valuations of their firms. The results are consistent with this assumption. Two controls appeared significant in the regressions. Beijing based VC firms are more likely to increase the initial value of firms. A possible explanation is that these funds are likely to have more government money and thus be cash rich because of their proximity to the central government, major R\&D institutes and universities, and government sponsored high tech zones such as Zhong Guan Cun in north Beijing. This soft budget constraint (Kornai, 1992) may be reflected in better values of friendly firms. Experienced fund managers are more likely to appreciate venture values. This is plausible for two reasons. Experienced investors may deliberately put lower values at the beginning so that we would have a larger room for concessions in the future. Making concessions in venture values may send a signal of commitment to the entrepreneurial team and this may enhance competitive advantage of investors in getting best projects. Because of their accumulated knowledge and experience, "veteran" investors are more likely to pick up better projects at the screening stage, and this increases the likelihood of appreciation in venture values.

Relational strength does matter in venture valuations. Intense information exchange between friends promotes confidence in entrepreneurial success on both sides, fund provider and seeker. Confident venture capitalists are more likely to put higher numbers on new firms (Zacharakis \& Shepherd, 2001). Friendship "myopia” or biases are likely to overlook potential downsides, and this affects valuations in favor of the entrepreneurial team. Strong ties lead to tacit understandings and expectations of investors on involvement in crucial financial and strategic decisions as an exchange pay-back for better values. The human equation- liking and emotional attachment is likely to be a factor in the culture of ren qing. 
A Confucian exchange tactic of giving more in expectation of getting more is at work: by valuing firms higher investors do accumulate "social receivables", and these monetary favors in advance are used as an influence leverage over entrepreneurs. This could be a crucial risk mitigating technique especially in bad times. Exchange favors without binding agreements are likely to promote further trust in investor-entrepreneur relationships (Molm, Takahashi, \& Peterson, 2000).

Although not robust, the evidence on Hypothesis Four supports tentatively our statement: friendly relations have reverse effects on investment delivery speed. "Excessive" information flows in both directions makes decision-making less efficient. A sense of accessibility, proximity and certainty leads to "complacency" of investors and entrepreneurs, and re-directs attention and time to other competing activities. In the Chinese mind, forward and backward actions in exchange processes are as important as outcomes. The Chinese therefore are more inclined to play "the Chinese chess" with their friends.

Stronger relationships lead to fewer contractual warrants that protect directly the investor's interests (Hypothesis Five). Investment contracts of friendly investors and entrepreneurs do contain fewer terms due to the strong trust between friends. Venture capitalists do not formalize many terms in warrants because of its positive perceptual and signaling effects on the entrepreneurial team. Less formalization indicates the commitment to share risks with the management team, and this in its turn deepens trust between the sides. In friendly circumstances, investors seem prefer fewer, clearly defined provisions in contrast to numerous and vaguely defined terms, which may jeopardize their personal friendship with the entrepreneur. In addition, the Chinese are more likely to rely on guanxi mechanisms and channels to protect their interests than contractual warrants that may be impossible to reenforce given the legal and institutional deficiencies. 
In high uncertainty and instrumentality context such as new venture finance, actors are likely to structure and categorize risks to maximize utility. Investors are likely to employ universal and industry wide criteria to mitigate risks that minimize utility outcomes directly. In the venture capitalist context, risks that minimize utility benefits directly are technology/products risks, management team risks, and growth perspective risk. Therefore, investors as rational players make decisions based on universal criteria. However, venture capitalists are likely to employ particularistic criteria such as social relationships in dealing with social uncertainties that may or may not decrease utility outcomes directly. Thus, social capital of entrepreneurs has enhancing effects on investment selection and main effects on investment processes.

\section{LIMITATIONS AND IMPLICATIONS}

Several limitations of this study should be discussed. This is a retrospective study about past investment decisions, and therefore, there might be an issue of to what extent respondents recall accurately information on past investment decisions. We used social capital measurements that were developed in the Western context for measuring an indigenous social phenomenon deeply rooted in Eastern and Confucius cultures - guanxi. We think therefore that there might be important features of guanxi that our measurements simply did not capture. The venture capital industry in the People's Republic of China is young. This macro institutional condition may have affected our results although we assume all the respondents have been exposed to the same conditions to the same extent. For example, many forms of warrants are unknown in China although we found enough variations in our variable on contractual provisions.

An important theoretical implication is that why and how, and in what contexts other than new venture finance social capital does have supplementary or enhancing effects on 
outcome variables should be further elaborated. Another equally important implication is that we should design and employ more indigenous systematic measurements that capture unique features of social relationships in different cultural and societal contexts. This will enrich our knowledge on methodologies of social network research. Interesting aspects of future research on guanxi are negative effects of positive guanxi and positive effects of negative guanxi. For example, to what extent favoritism in relationships or high network closure in clique-type clusters do affect outcome variables negatively? To what extend, perceived negative relationships do have positive effects on outcome variables?

An implication for entrepreneurship research is to examine impacts of the way in which venture capital was raised on firm performance. For example, whether firms which raised private equity through personal relationships do better than those firms which did not raise venture capital through personal ties. An interesting issue may be how and when superstrong ties or over-embeddedness does affect negatively entrepreneurial performance.

Finally, dynamics of guanxi, i.e., changes in network structures and relations over time, is an interesting theme given the social and economic changes that are taking place in China.

\section{CONCLUSION}

The main finding of this study is that in high uncertainty and high utility maximizing context such as new venture finance, social capital has enhancing effects on investment selection as opposed to main effects in the screening stage due to the risk mitigating role. Once the venture passes the threshold of being funded, strong ties are at work independent of other factors. 


\section{LITERATURE}

Aldrich, H. \& Zimmer, C. (1986), "Entrepreneurship Through Social Networks," in D. Sexton and R. Smilor (Eds), The Art and Science of Entrepreneurship, Cambridge, Mass: Ballinger Publishing, 3-23.

Baker, W. (1990), “Market networks and corporate behavior,” American Journal of Sociology, 96 (3): 589625 .

Batjargal, B. (2000), "Effects of Networks on Entrepreneurial Performance in a Transition Economy: The Case of Russia," Reynolds, P. et al, (Eds), Frontiers of Entrepreneurship Research, Babson College, Mass.

Batjargal, B. (2002), "The Dynamics of Entrepreneurial Networks in a Transition Economy: The Case of Russia," Entrepreneurship Theory and Practice, forthcoming

Belliveau, M, O’Reilly, C, \& Wade, J (1996), "Social capital at the top: Effects of social similarity and status on CEO compensation." Academy of Management Journal, 39(6): 1568-1593.

Bian, Y. (2001), "Guanxi Capital and Social Eating in Chinese Cities", in N. Lin, K. Cook, \& R. Burt, (Eds), Social Capital, Theory and Research, New York: Aldine De Gruyter, 275-295.

—\& Ang, S. (1997), “Guanxi Networks and Job Mobility in China and Singapore”, Social Forces, 75: 9811005.

Birley, S. (1985), "The Role of Networks in the Entrepreneurial Process." Journal of Business Venturing, 1(1): 107-117.

Bourdieu, P. (1986), "The forms of capital", Handbook of Theory and Research for the Sociology of Education, New York: Greenwood, 241-258.

Brealey, R. \& Myers, S. (1996), Principles of Corporate Finance, Fifth edition, McGraw-Hill.

Brush, C., Carter, N., Greene, P., Hart, M., \& Gatewood, E., (2000), "Women and Equity Capital: An Exploration of Factors Affecting Capital Access," in P. Reynolds, et al., (Eds), Frontiers of Entrepreneurship Research, Babson College.

Burt, R. (1992) Structural Holes, The Social Structure of Competition, Cambridge: Harvard University Press.

— (1997), “The contingent value of social capital,” Administrative Science Quarterly, 42: 339-365.

Butler, J. B. Brown, \& W. Chamornmarn, (2000), "Guanxi and the Dynamics of Overseas Chinese Entrepreneurial Behavior in South East Asia", in J.T. Li, A. Tsui \& E. Weldon, (Eds), Management and Organization in the Chinese context, London: Macmillan, 245-268.

Bygrave, W. \& J. Timmons, (1992), Venture Capital at the Cross Roads, Boston: Harvard Business School Press.

Bygrave, W. G. Johnstone, J. Lewis, \& R. Ullman, (1998), "Venture Capitalists' Criteria for Selecting HighTech Investments: Prescriptive Wisdom Compared with Actuality," in P. Reynolds, et al., (Eds), Frontiers of Entrepreneurship Research, Babson College, 544-555.

Cable, D. \& Shane, S. (1997), “A Prisoner's Dilemma Approach to Entrepreneur-Venture Capitalist Relationship," in Academy of Management Review, 22(1): 142-176.

Cheng, S. (2000), Government and Venture Capital, Beijing: China Democratic and Construction Publishing, in Chinese. 
William Davidson Institute Working Paper 453

Cheung T. S. \& King, A. (2001), “A Study of Confucian Entrepreneurs in Mainland China, Taiwan, and Hong Kong”, in A. So, N. Lin, and D. Poston (Eds), The Chinese Triangle of Mainland China, Taiwan, and Hong Kong, Comparative Institutional Analysis, London: Greenwood Press, 43-58.

Child, J. \& Boisot, M. (1996), "From Fiefs to Clans and Network Capitalism: Explaining China's Emerging Economic Order," Administrative Science Quarterly, 41: 600-628.

Coleman, J. (1988), "Social capital in the creation of human capital," American Journal of Sociology, 94: S95S120.

Farh, L. Tsui, A. Xin, K. \& Cheng, B. (1998), "The Influence of Relational Demography and Guanxi: The Chinese Case", Organization Science, 9 (4): 471-488.

Fernandez, R. Castilla, E. \& Moore, P. (2000), "Social Capital at Work: Networks and Employment at a Phone Center," American Journal of Sociology, 105 (5): 1288-1356.

FlapH. \& Boxman, E. (2001), "Getting Started: The Influence of Social Capital on the Start of the Occupational Career", in N. Lin, K. Cook, and R. Burt (Eds), Social Capital: Theory and Research, New York: Aldine De Gruyter, 159-181.

Gompers, P \& Lerner, J. (2000), The Venture Capital Cycle, Cambridge, MIT Press.

Gompers, P., (1995), “Optimal Investment, Monitoring, and the Staging Venture Capital”, Journal of Finance, 5: 1461-1489.

Granovetter, M. S. (1973), “The Strength of Weak Ties,” American Journal of Sociology, 78, 1360-1380.

- (1985), "Economic Action and Social Structure: The Problem of Embeddedness", American Journal of Sociology, 91 (3): 481-510.

Hall J. \& Hofer, C. (1993), "Venture Capitalist's Decision Criteria in the New Venture Evaluation”, Journal of Business Venturing, 8 (1): 25-42.

Hellmann, T. (1998), "The Allocation of Control Rights in Venture Capital Contracts", Rand Journal of Economics, 29 (1): 57-76.

— \& Puri, M. (2000), "The Interaction Between Product Market and Financing Strategy: The Role of Venture Capital”, The Review of Financial Studies, 13 (4): 959-984.

Hisrich, R. \& Jancowicz, (1990), “Intuition in Venture Capital Decisions: An Exploratory Study using a New Technique", Journal of Business Venturing, 5:49-62.

Jaccard, J. (2001), Interaction Effects in Logistic Regression, London: Sage.

Kaplan, S. \& P. Stromberg, (2000), "Venture Capitalists as Principals: Contracting, Screening, and Monitoring”, manuscript, Graduate School of Business, University of Chicago.

King, A. (1985), “The Individual and Group in Confucianism: A Relational Perspective”, D. Munro, (Ed), Individualism and Holism: Studies in Confucian and Taoist Values, Ann Arbor: University of Michigan Press, $57-70$.

Kornai, J. (1992), The Socialist System: the Political Economy of Communism, Princeton, N.J.: Princeton University Press.

Krackhardt, D. (1990), "Assessing the political landscape: structure, cognition, and power in organizations," Administrative Science Quarterly, 35: 342-369. 


\section{William Davidson Institute Working Paper 453}

— (1998), "Simmelian Ties: Super Strong and Sticky", in R. Kramer \& A. Neale, (Eds), Power and Influence in Organizations, Sage Publications, 21-38.

Landstrom, H. (1998), "Contracts Between Entrepreneurs and Investors: Terms and Negotiation Processes", in P. Reynolds, et al., (Eds), Frontiers of Entrepreneurship Research, Babson College, 571-585.

Larson, A. (1992), "Network Dyads in Entrepreneurial Settings: A study of the Governance of Exchange Relationships," Administrative Science Quarterly, 37: 76-104.

Lerner, J., (1995), Venture Capitalists and the Oversight of Private Firms", Journal of Finance, 1: 301-318.

Lin, N. (2001a), Social Capital: A Theory of Social Structure and Action, Cambridge University Press.

- (2001b), "Building a Network Theory of Social Capital", in N. Lin, K. Cook, and R. Burt (Eds), Social Capital: Theory and Research, New York: Aldine De Gruyter, 3-29.

- (2001c), "Guanxi: A Conceptual Analysis", in A. So, N. Lin, and D. Poston (Eds), The Chinese Triangle of Mainland China, Taiwan, and Hong Kong, Comparative Institutional Analysis, London: Greenwood Press, 153-166.

- Vaughn, J. \& Ensel, W. (1981) "Social resources and occupational status attainment." Social Forces, 59(4): 1163-81.

- Fu. Y. \& Hsung, R. (2001), "The Position Generator: Measurement Techniques for Investigations of Social Capital", in N. Lin, K. Cook, and R. Burt (Eds), Social Capital: Theory and Research, New York: Aldine De Gruyter, 57-81.

Liu, M. (1999), Venture Capital in China: Ten Most Illusive Traps, Beijing: Economic Daily, in Chinese.

Liu, M. \& Y. Wang, (2001), Venture Capital: Attractive Opportunities in China, Beijing: China Business, in Chinese.

Liu, M. et al., (2002) China Venture Capital Yearbook, in Chinese, Beijing: Renmin University, in Chinese, forthcoming.

London Business School, (1997), Valuation Issues in Start-Ups and Early-Stage Companies: The Venture Capital Method.

Macmillan, I. Siegel, R. \& Subba Narasimha, (1985), "Criteria Used by Venture Capitalists to Evaluate New Venture Proposals," Journal of Business Venturing, 1: 119-128.

—Zeman, L. \& Subba Narasimha, (1987), "Criteria Distinguishing Successful from Unsuccessful Ventures in the Venture Screening Process," Journal of Business Venturing, 2: 122-137.

March, J. (1988), Decisions and Organizations, Oxford: Basil Blackwell.

Marsden, P. \& Hurlbert, J. (1988), "Social resources and mobility outcomes: A replication and extension," Social Forces, 67: 1038-1059.

McCullagh, P. \& J. A. Nelder, (1999), Generalized Linear Models, Second edition, New York: Chapman \& Hall.

Molm, L. Takahashi, N. \& Peterson, G. (2000), "Risk and Trust in Social Exchange: An Experimental Test of Classical Proposition", American Journal of Sociology, 105 (5): 1396-1427.

Muzyka, D. Birley, S. \& Leleux, (1996), "Trade-offs in the Investment Decisions of European Venture Capitalists,” Journal of Business Venturing, 11: 273-287. 


\section{William Davidson Institute Working Paper 453}

Nee, V., (1992), "Organizational Dynamics of Market Transition: Hybrid Forms, Property Rights, and Mixed Economy in China," Administrative Science Quarterly, 37: 1-27.

Nohria, N. (1992), "Information and Search in the Creation on New Business Ventures: the Case of the 128

Venture Group, in N. Nohria \& R. Eccles, (Eds), Networks and Organizations: Structure, Form, and Action, Boston: Harvard Business School, 240-261.

Oi, J. (1992), "Fiscal Reform and the Economic Foundations of Local State Corporatism in China,", World Politics, 45: 99-126.

Peng, M. (2001), "How Entrepreneurs Create Wealth in Transition Economies", Academy of Management Executive, 15 (1): 95-108.

— \& Y. Luo, (2000), "Managerial Ties and Firm Performance in a Transition Economy: the Nature of a Micro-macro Link," Academy of Management Journal, 43 (3): 486-501.

Pfeffer, J. G. Salancik, \& H. Leblebici, (1976), "The Effect of Uncertainty on the Use of Social Influence in Organizational Decision Making,” Administrative Science Quarterly, 21 (6): 227-245.

Podolny, J. (1994), "Market Uncertainty and the Social Character of Economic Exchange", Administrative Science Quarterly, 39: 458-83.

— \& Baron, J. (1997), "Resources and relationships: social networks and mobility in the work place," American Sociological Review, 62: 673-93.

— \& Castelucci, F. (1999), "Choosing Ties from the Inside of a Prism: Egocentric Uncertainty and Status in Venture Capital Markets", in R. Leenders \& S. Gabbay, (Eds), Corporate Social Capital and Liability, London: Kluwer Academic Publishers, 431-445.

Quanyu, H. Leonard, J. \& Tong, C. (1997), Business Decisions Making in China, London: International Business Press.

Sahlman, W. (1990), "The Structure and Governance of Venture Capital Organizations", Journal of Financial Economics, 27: 473-521.

Sapienza, H. (1992), “When Do Venture Capitalists Add Value?,” Journal of Business Venturing, 7: 9-27.

— \& Korsgaard, M. (1996), "The Role of Procedural Justice in Entrepreneur-Venture Capital Relations," Academy of Management Journal, 39: 544-574

Shane, S. \& Cable, D. (2001), "Social Relationships and the Financing of New Ventures", University of Maryland, manuscript.

Smart, G. (1998), "Management Assessment Methods in Venture Capital: Towards a Theory of Human Capital Valuation," in P. Reynolds et al, (Eds), Frontiers of Entrepreneurship Research, Babson College, 600-612.

Sorenson, O. \& Stuart, T. (2001), "Syndication Networks and the Spatial Distribution of Venture Capital Investments", American Journal of Sociology, 106 (6): 1546-88.

State Industrial and Commercial Registration Bureau, (2000), Yearbook, Beijing: Industrial \& Commercial Publishing House.

Stinchcombe, A. (1965), "Social structure and organisations"in J. March. (Ed), Handbook of organisations, Chicago: Rand McNally, 142-93.

Stuart, T. Hoang, H. \& Hybels, R. (1999), "Interorganizational endorsement and the performance of entrepreneurial ventures," Administrative Science Quarterly, 44:315-349. 


\section{William Davidson Institute Working Paper 453}

Timmons, J. (1994), New Venture Creation, Entrepreneurship for the $21^{\text {st }}$ Century, Fourth edition, Irwin

Tsai, W. \& Ghoshal, S. (1998), "Social capital and value creation: The role of intrafirm networks," Academy of Management Journal, 41 (4): 464-476.

Tsui, A. Egan, T. \& O'Reilly, C. "Being Different: Relational Demography and Organizational Attachment", Administrative Science Quarterly, 37: 549-579.

Tsui, A. \& Farh, J.L. (1997), “Where Guanxi Matters”, Work and Occupations, 24 (1): 56-79.

Tsui, A. Farh, J.L. \& K. Xin, (2000), “Guanxi in the Chinese context”, in J.T. Li, A. Tsui \& E. Weldon, (Eds), Management and Organization in the Chinese context, London: Macmillan, 225-244.

Walker, G. Kogut, B. \& Shan, W. (1997), "Social capital, structural holes, and the formation of an industry network," Organization Science, 8(2): 109-125.

Walder, A. (1986), Communist Neo-Traditionalism: Work and Authority in Chinese Industry, Berkeley, CA: University of California Press.

Wasserman, S. \& K. Faust, (1994), Social Network Analysis, Methods and Applications, Cambridge: Cambridge University Press.

Xin, K. \& Pearce, J. (1996), “Guanxi: Connections as Substitutes for Formal Institutional Support”, Academy of Management Journal, 39: 1641-1658.

Uzzi, B. (1999), "Embeddedness in the Making of Financial Capital: How Social Relations and Networks Benefit Firms Seeking Finance", American Sociological Review, 64: 481-505.

Yang, M. (1994), Gifts, Favors, and Banquets: The Art of Social Relationships in China, Ithaca, NY: Cornell University Press.

Yeung. I. \& R. Tung, (1996), “Achieving Business Success in Confucian Societies: The Importance of Guanxi (Connections)", Organizational Dynamics, 25 (2): 54-65.

Zacharakis, A. \& Shepherd, D. (2001), "The Nature of Information and Overconfidence on Venture Capitalists' Decision Making”, Journal of Business Venturing, 16: 311-332.

Zhang, J. (2000), New Millennium Venture Capital Series, Beijing: China Finance Publishing, in Chinese.

Zhang, L. (2001), High Tech Entrepreneurship and Venture Capital, Beijing: in Chinese. 
William Davidson Institute Working Paper 453

TABLE 1. Venture Capital Firms in China

\begin{tabular}{|c|c|c|c|c|}
\hline & $\overline{\mathbf{N}}$ & $\begin{array}{l}\text { Investment } \\
\text { Policy }\end{array}$ & Location & $\begin{array}{c}\text { Funds under } \\
\text { management } \\
\text { (\$US) }\end{array}$ \\
\hline $\begin{array}{l}\text { VC firms financed by } \\
\text { governments }\end{array}$ & 60 & All industries & $\begin{array}{l}\text { Provincial } \\
\text { centers }\end{array}$ & $>25$ million \\
\hline $\begin{array}{l}\mathrm{VC} \text { firms financed by } \\
\text { private individuals }\end{array}$ & 30 & Hi-tech focus & Major cities & $\leq 12.5$ million \\
\hline Foreign VC firms & 60 & $\begin{array}{l}\text { Information } \\
\text { technology } \\
\text { focus }\end{array}$ & $\begin{array}{l}\text { Beijing } \\
\text { Shanghai } \\
\text { Shenzhen }\end{array}$ & $\begin{array}{l}40-60 \\
\text { million* }\end{array}$ \\
\hline $\begin{array}{l}\text { VC firms financed by } \\
\text { public companies }\end{array}$ & 20 & Hi-tech focus & Major cities & 1-6 million \\
\hline $\begin{array}{l}\text { VC firms financed by } \\
\text { financial institutions }\end{array}$ & 10 & All industries & Capital cities & \\
\hline
\end{tabular}

TABLE 2. General Partners of VC Firms

\begin{tabular}{|c|c|c|c|}
\hline & $\mathbf{N}$ & Mean & Std. D. \\
\hline Beijing dummy & 42 & 0.55 & 0.50 \\
\hline Shanghai dummy & 42 & 0.45 & 0.50 \\
\hline Male dummy & 42 & 0.92 & 0.26 \\
\hline BA education dummy & 42 & 0.21 & 0.41 \\
\hline Master's education dummy & 42 & 0.64 & 0.48 \\
\hline Doctoral education dummy & 42 & 0.14 & 0.35 \\
\hline Age of general partner & 40 & 35 & 5.78 \\
\hline
\end{tabular}



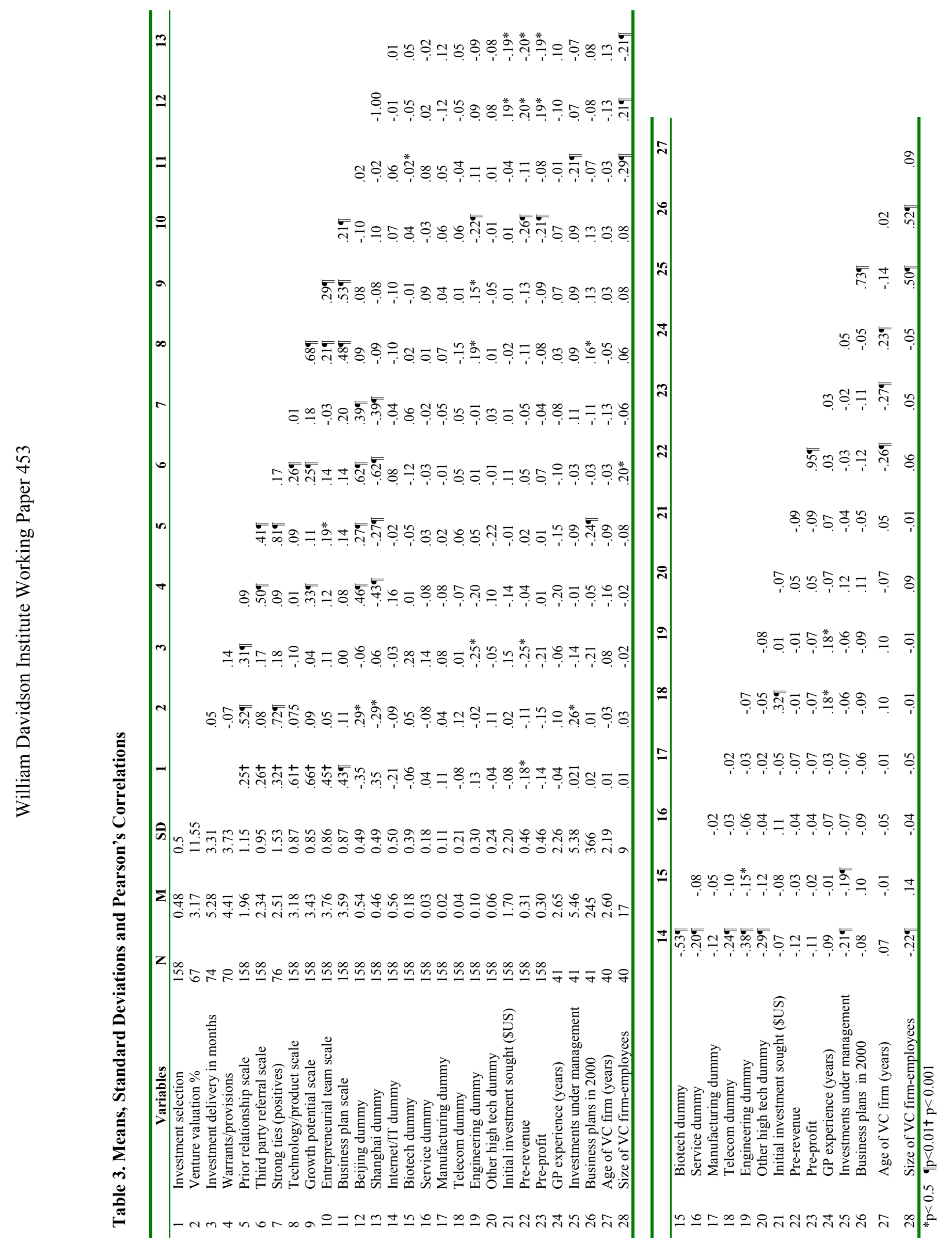


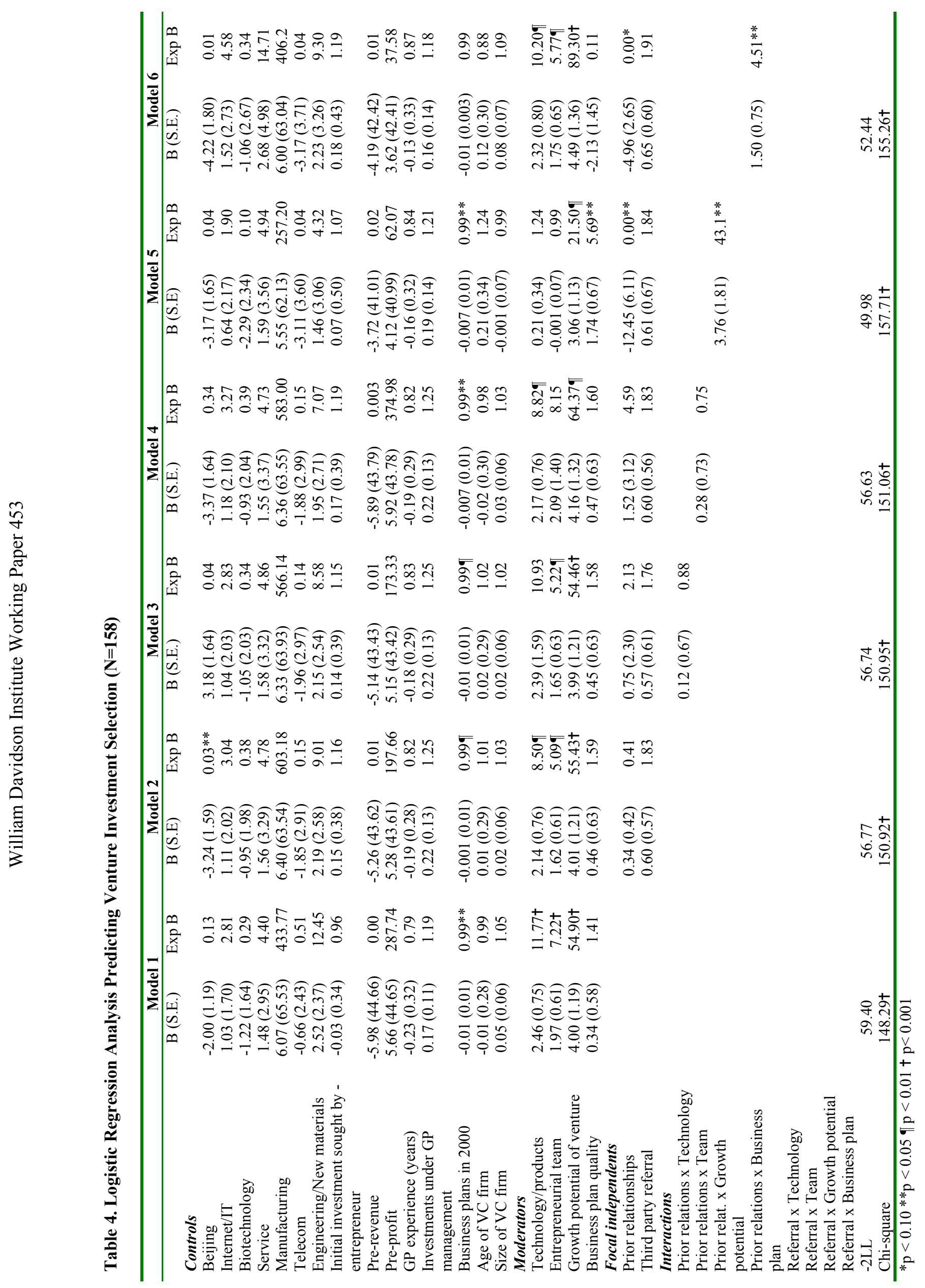




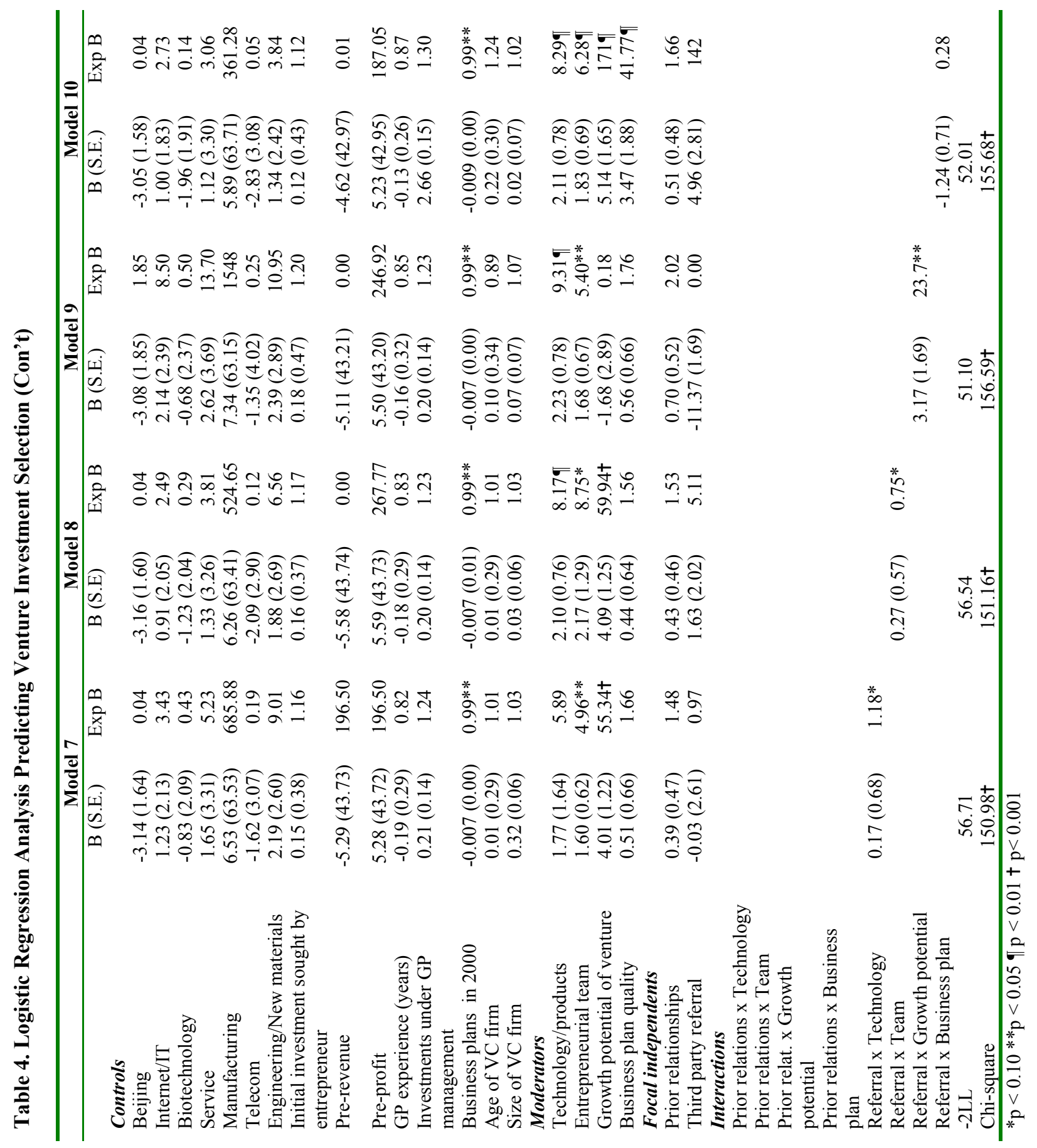




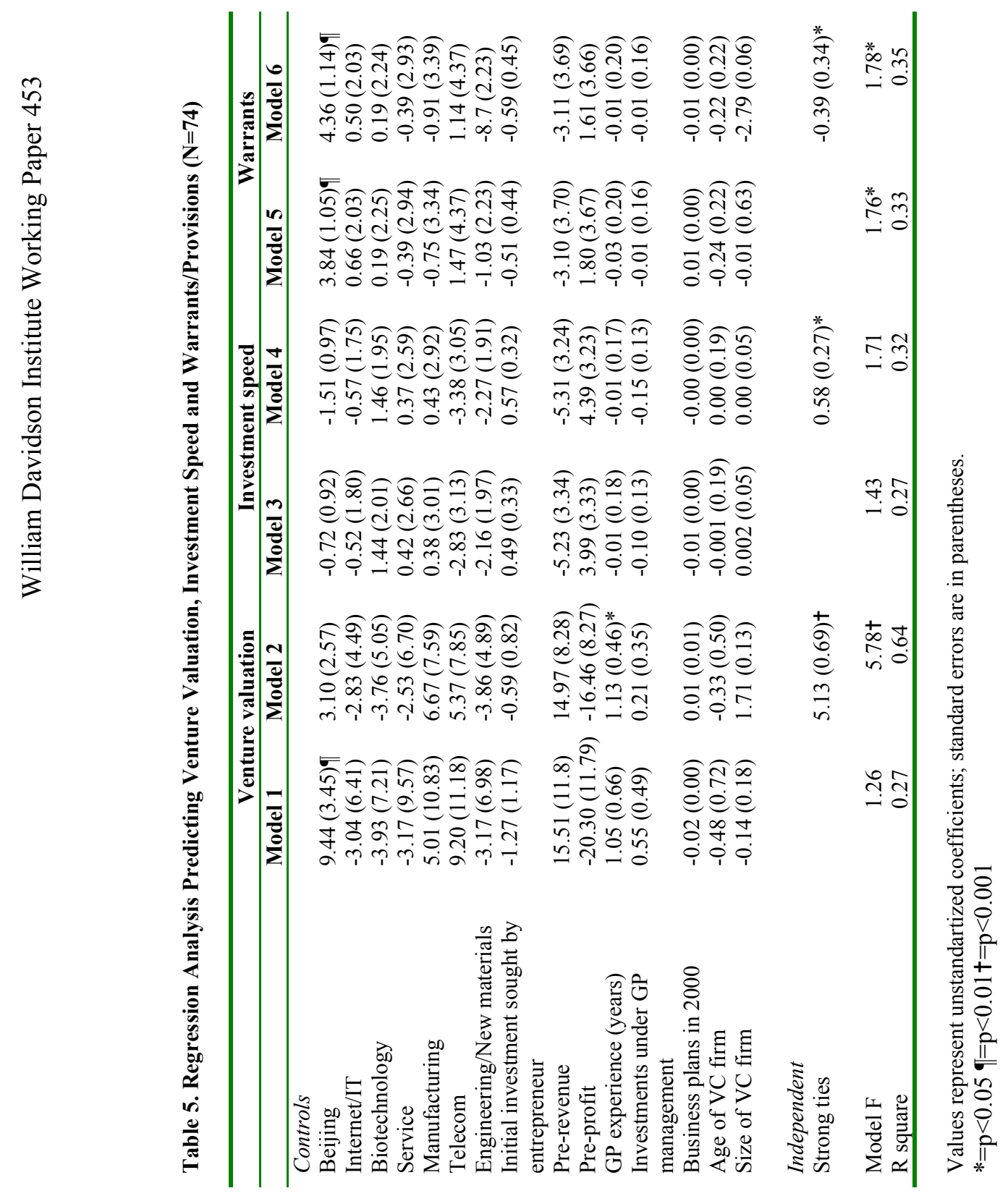




\section{DAVIDSON INSTITUTE WORKING PAPER SERIES - Most Recent Papers}

The entire Working Paper Series may be downloaded free of charge at: www.wdi.bus.umich.edu

CURRENT AS 4/5/02

\begin{tabular}{|c|c|c|}
\hline Publication & Authors & Date \\
\hline $\begin{array}{l}\text { No. 453: Entrepreneurs' Access to Private Equity in China: } \\
\text { The Role of Social Capital }\end{array}$ & Bat Batjargal and Mannie M. Liu & Apr. 2002 \\
\hline $\begin{array}{l}\text { No. 452: The Determinants of Privatised Enterprise Performance in } \\
\text { Russia }\end{array}$ & $\begin{array}{l}\text { Alan A. Bevan, Saul Estrin, Boris } \\
\text { Kuznetsov, Mark E. Schaffer, } \\
\text { Manuela Angelucci, Julian } \\
\text { Fennema and Giovanni } \\
\text { Mangiarotti }\end{array}$ & June 2001 \\
\hline $\begin{array}{l}\text { No. 451: Determinants of Financial Distress: What Drives Bankruptcy } \\
\text { in a Transition Economy? The Czech Republic Case }\end{array}$ & Lubomír Lízal & Jan. 2002 \\
\hline No. 450: Corporate Governance and the Global Social Void & Lee A. Tavis & Oct. 2001 \\
\hline $\begin{array}{l}\text { No. 449: Financial Architecture and Economic Performance: } \\
\text { International Evidence }\end{array}$ & Solomon Tadesse & Aug. 2001 \\
\hline $\begin{array}{l}\text { No. 448: Growth Slowdown Under Central Planning: A Model of Poor } \\
\text { Incentives }\end{array}$ & Zuzana Brixiová and Aleš Bulíř & Mar. 2002 \\
\hline $\begin{array}{l}\text { No. 447: Disentangling Treatment Effects of Polish Active Labor } \\
\text { Market Policies: Evidence from Matched Samples }\end{array}$ & $\begin{array}{l}\text { Jochen Kluve, Hartmut Lehmann, } \\
\text { and Christoph M. Schmidt }\end{array}$ & Jan. 2002 \\
\hline $\begin{array}{l}\text { No. 446: The Impact of Socialist Imprinting and Search for Knowledge } \\
\text { on Resource Change: An Empirical Study of Firms in Lithuania }\end{array}$ & $\begin{array}{l}\text { Aldas Kriauciunas and Prashant } \\
\text { Kale }\end{array}$ & Mar. 2002 \\
\hline $\begin{array}{l}\text { No. 445: The Costs, Wealth Effects, and Determinants of International } \\
\text { Capital Raising: Evidence from Public Yankee Bonds }\end{array}$ & $\begin{array}{l}\text { Darius P. Miller and John J. } \\
\text { Puthenpurackal }\end{array}$ & Oct. 2001 \\
\hline No. 444: Financial Institutions, Contagious Risks, and Financial Crises & $\begin{array}{l}\text { Haizhou Huang and Chenggang } \\
\mathrm{Xu}\end{array}$ & Nov. 2001 \\
\hline No. 443: Banks as Catalysts for Industrialization & $\begin{array}{l}\text { Marco Da Rin and Thomas } \\
\text { Hellmann }\end{array}$ & Oct. 2001 \\
\hline $\begin{array}{l}\text { No. 442: Bank-Based or Market-Based Financial Systems: Which is } \\
\text { Better? }\end{array}$ & Ross Levine & Feb. 2002 \\
\hline $\begin{array}{l}\text { No. 441: Migration and Regional Adjustment and Asymmetric Shocks } \\
\text { in Transition Economies }\end{array}$ & Jan Fidrmuc & Feb. 2002 \\
\hline $\begin{array}{l}\text { No. 440: Employment and Wages in Enterprises Under Communism } \\
\text { and in Transition: Evidence From Central Europe and Russia }\end{array}$ & $\begin{array}{l}\text { Swati Basu, Saul Estrin, and Jan } \\
\text { Svejnar }\end{array}$ & June 2000 \\
\hline No. 439: Small business in Russia: A Case Study of St. Petersburg & Alessandro Kihlgren & Jan. 2002 \\
\hline $\begin{array}{l}\text { No. 438: Foreign Direct Investment as Technology Transferred: } \\
\text { Some Panel Evidence from the Transition Economies }\end{array}$ & $\begin{array}{l}\text { Nauro F. Campos and Yuko } \\
\text { Kinoshita }\end{array}$ & Jan. 2002 \\
\hline No. 437: Whistleblowing, MNC's and Peace & Terry Morehead Dworkin & Feb. 2002 \\
\hline $\begin{array}{l}\text { No. 436: A Note on Measuring the Unofficial Economy in the Former } \\
\text { Soviet Republics }\end{array}$ & $\begin{array}{l}\text { Michael Alexeev and William } \\
\text { Pyle }\end{array}$ & Sept. 2001 \\
\hline $\begin{array}{l}\text { No. 435: The Ownership School vs. the Management School of State } \\
\text { Enterprise Reform: Evidence from China }\end{array}$ & David D. Li and Changqi Wu & Jan. 2002 \\
\hline $\begin{array}{l}\text { No. 434: The Effect of Ownership and Competitive Pressure on Firm } \\
\text { Performance in Transition Countries: Micro Evidence from Bulgaria, } \\
\text { Romania and Poland. }\end{array}$ & $\begin{array}{l}\text { Manuela Angelucci, Saul Estrin, } \\
\text { Jozef Konings, and Zbigniew } \\
\text { Zolkiewski }\end{array}$ & Jan. 2002 \\
\hline No. 433: The End of Moderate Inflation in Three Transition Economies? & Josef C. Brada and Ali M. Kutan & Jan. 2002 \\
\hline $\begin{array}{l}\text { No. 432: What Drives the Speed of Job Reallocation During Episodes of } \\
\text { Massive Adjustment? }\end{array}$ & $\begin{array}{l}\text { Stepan Jurajda and Katherine } \\
\text { Terrell }\end{array}$ & Jan. 2002 \\
\hline $\begin{array}{l}\text { No. } 431 \text { Forthcoming in: The Journal of Economic Perspectives, } \\
\text { "Competition and Corporate Governance in Transition," 16(2) Feb. } \\
2002 .\end{array}$ & Saul Estrin & Dec. 2001 \\
\hline $\begin{array}{l}\text { No. 430: Corporate Governance in the Cause of Peace: An } \\
\text { Environmental Perspective }\end{array}$ & Don Mayer & Jan. 2002 \\
\hline
\end{tabular}

